\title{
Van Dis skryf oor Suid-Afrika se verwoestende towerpoeier
}

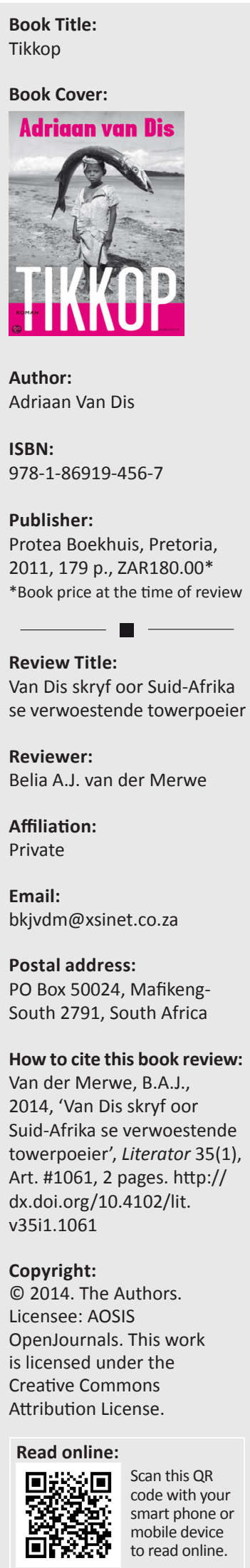

Sedert die verskyning van Het beloofde land (1990), 'n outobiografiese verslag van 'n reis deur die Karoo, is die Nederlandse skrywer Adriaan van Dis bekend by Afrikaanse lesers. Twintig jaar later, in 2010, verskyn daar weer uit sy pen 'n werk wat in Suid-Afrika afspeel - die roman Tikkop wat deur Daniel Hugo in Afrikaans vertaal is in 2011.

Die hooffiguur en fokalisator is weereens, soos in Van Dis (2007) se roman De wandelaar, die alleenloper Mulder, 'n Nederlander wat in Parys woon. Waar daar egter in De wandelaar gefokus word op die problematiek en oorlewingstryd van asielsoekers, onwettige immigrante, vlugtelinge en ander randfigure in een van Europa se hoofstede, neem Tikkop die Suid-Afrikaanse samelewing in die postapartheidsjare onder die loep.

Tydens 'n besoek aan 'n pas geopende Paryse museum loop Mulder een middag 'n ou vriend raak. Hy en Donald, albei nou iets in die 60 jaar oud, het mekaar aan die begin van die sewentigerjare in Parys leer ken toe beide deur die organisasie Fraternité opgelei is vir ondergrondse werk in Suid-Afrika. Donald nooi Mulder, wat nog nie volkome herstel het na 'n tweede beroerte nie, om na Suid-Afrika te kom. Hy voer aan dat dit goeie oefening vir Mulder se brein sal wees en hy hom dan sommer ook kan vergewis wat van hulle droom van destyds geword het (bl. 15).

Donald het vir Mulder 'n bouvallige huis te huur gekry op die vissersdorp langs die weskus waar hy self ook woon. Ofskoon Mulder se simpatie steeds by die onderdruktes en uitgeskoptes van die samelewing lê, word hy van meet af aan gekonfronteer deur die realiteit van die hedendaagse Suid-Afrika. In die krotbuurt van die vissersdorp maak hy kennis met die vyandigheid en venyn wat skynbaar oral net onder die oppervlak skuil toe hy onder aanhitsing van 'n klompie verwaarloosde kinders deur 'n worshond aan die been gebyt word.

Die 'tikkop' van die titel kom vroeg in die roman al ter sprake. Mulder se buurvrou noem Hendrik, die seun met die gebreekte arm wat hulle 'n geleentheid dorp toe gee, 'n tikkop. Sy verduidelik dat tik, oftewel crystal meth 'n soort dwelm is, 'n bendedwelm wat jou brein, jou gevoel, jou gewete opvreet (bl. 33). Mettertyd hoor Mulder meer van hierdie towerpoeier, hierdie listige slang wat hele gesinne verwoes. Dis maklik om in die hande te kry; van die dorp se inwoners beweer selfs dat dit gratis by die skool uitgedeel word. Hendrik vertel hoe tik gekook en gerook word. Nie op 'n lepel nie:

maar met 'n gloeilamp. Jy moet die indraaideel afslaan, die poeier in die glas gooi, 'n vlam onder hou tot dit borrel, die damp intrek en dan wag tot jou brein teen jou skedel tik. (bl. 154)

Mulder en Donald raak betrokke by Hendrik, hulle neem hom by hulle in die huis en probeer hom van sy verslawing genees. Die gebeure word op die spits gedryf as Hendrik alle pogings om hom te help in die wind slaan en hom met Mulder se skootrekenaar, klere, ' $n$ kissie Kaapse silwerware en ander items uit die voete maak. Die twee weldoeners moet ook hoor dat daar 'n klag teen hulle ingedien is. Hulle goeie bedoelings het dus op niks uitgeloop nie en uiteindelik moet hulle as't ware uit die dorp vlug.

Saam met hierdie gebeure wat in die hede afspeel, ontvou die verhaal van Mulder en Donald se destydse kennismaking en hul opleiding in Parys. Mulder word deur Cathérine, 'n vrysinnige jong vrou uit Suid-Afrika aan die organisasie bekend gestel. Hier ontmoet hy vir Donald, die seun van 'n vooraanstaande Afrikaner, wat alle bande met sy familie verbreek het en as skoonmaker in 'n hospitaal werk om sy mediese studie te betaal.

In solderkamers in Parys leer Mulder, wat aan almal in die organisasie as Marten bekend is, en Donald (dit is ook nie sý regte naam nie) geheime kodes, en hoe om briewe in onsigbare ink te skryf. Hulle word opgelei in die agtervolgkuns en leer om 'n pistool vinnig en akkuraat te gebruik. Vir die saak - pour la cause - breek hulle by ambassadepersoneel in, installeer afluisterapparaat en versteek mikrofilms in uitgeholde Bybels. Onder aansporing van Cathérine onderneem Mulder, as 'n onsigbare buitestander, 'n verbode reis na Suid-Afrika - met verreikende en tragiese gevolge. 
Onafgehandelde sake uit hulle gedeelde verlede lei nou tot spanning tussen Mulder en Donald. Namate die vyandigheid van die vissersgemeenskap teenoor hulle toeneem, word die konflik tussen die eertydse kamerade ook op die spits gedryf. Hulle moet uiteindelik vrede maak met gebeure uit die verlede en erken dat hulle al twee skuldig was aan verraad teenoor Cathérine. Mulder kom ook tot die besef dat hy hom deur Cathérine aan 'n bitter stryd laat bind het wat nooit werklik syne was nie en dat hy sonder haar ver van hierdie besmette land sou gebly het.

Die hedendaagse Suid-Afrika wat in die roman beskryf word, is egter steeds 'n 'besmette' land. Misdaad, korrupsie, geweld en opstokery is aan die orde van die dag. Die bruin vissers word van alle kante uitgebuit en voel dat hulle steeds van apartheid nie bevry is nie. Witmense leef in vrees agter hoë mure en elektriese heinings, of verlaat die land. Donald bely teenoor Mulder dat hy al hoe meer voel soos 'n vreemdeling in sy eie land: 'Deep down is ek bang dat ek nie hier hoort nie' (bl. 169). Tog eindig Mulder se besoek aan Suid-Afrika, sowel as die roman, op 'n effens meer positiewe noot. Op sy laaste oggend in die Kaap blaai hy deur die koerante. Hy slaan die baie bloed en sport oor - dit moet sorg vir goeie verkope - en kom tot die gevolgtrekking: 'Agter die sensasie glimmer 'n beter toekoms - die land het groot verwagtings' (bl. 176).

Tikkop is die resultaat van deeglike navorsing, soos Van Dis agter in die roman aantoon. Danksy Daniel Hugo se knap vertaling is dit 'n aangename leeservaring.

\section{Literatuurverwysings}

Van Dis, A., 1990, Het beloofde land, Uitgeverij Meulenhof, Amsterdam. Van Dis, A., 2007, De wandelaar, Uitgeverij Amstel, Amsterdam. 